\title{
Bolu İlinde Sığır Besiciliği ve Besiye Alınan Sığırlarda Bazı Vücut Öıçülerinin Belirlenmesi
}

\section{Onur ŞAHIN}

Muş Alparslan Üniversitesi, Uygulamalı Bilimler Fakültesi, Hayvansal Üretim ve Teknolojileri Bölümü, Muş https://orcid.org/0000-0002-3801-3881

$\bowtie$ : o.sahin@alparslan.edu.tr

\section{ÖZET}

$\mathrm{Bu}$ araştırmada, Bolu ilindeki sığır besi işletmelerinde besicilik faaliyetinin yapısal durumu ve besiye alınmış sığırların bazı vücut özelliklerinin belirlenmesi amaçlanmıştır. Araştırmanın materyalini sığır besisi yapılan 9 işletmede farklı genotip, cinsiyet ve yaş grubundan besiye alınan 339 baş besi sığırı oluşturmuştur. İşletmelerde besi faaliyetine ait bilgilerin toplanmasına ek olarak sı̆̆ırlar üzerinde cidago yüksekliği ve göğüs çevresi ölçülmüştür. İşletmeler, besideki hayvan sayısına göre 1-50 baş, 51 baş ve üzeri olarak gruplandırılmıştır. Bu gruplardaki hayvan sayıları ve genel ortalama bahsedildikleri sıra ile; 19.0 baş, 75 baş ve 37.7 baştır. Çalışmada besi başlangıcı ve besi sonu yaşları sırasıyla; $9.7 \pm 2,23$ yaş ve $25.6 \pm 3.57$ yaş olarak hesaplanmıştır. Ortalama besi süresi ise 15.9 $\pm 5,21$ ay olarak tespit edilmiştir. Siyah Alaca melezleri, Esmer melezleri, Simental melezleri ve yerli irklar için 9-12 aylık yaş ortalama canlı ağırlık sırasıyla; $233.9 \pm 15.25 \mathrm{~kg}, 252.7 \pm 24.33 \mathrm{~kg}$, $236.1 \pm 22.05 \mathrm{~kg}, 127.3 \pm 19.69 \mathrm{~kg}$ olarak tahmin edilmiştir. Aynı ırklar için 18-22 aylık yaş döneminde ortalama canlı ağırlık, aynı sıra ile; $432.3 \pm 42.31 \mathrm{~kg}, 420.5 \pm 22.19 \mathrm{~kg}, 440.4 \pm 37.10 \mathrm{~kg}, 212.5 \pm 20.31 \mathrm{~kg}$ olarak tahmin edilmiştir.

\section{Araştırma Makalesi}

Makale Tarihçesi
Geliş Tarihi $\quad: 08.06 .2020$
Kabul Tarihi $\quad: 10.09 .2020$

Anahtar Kelimeler

Siğır

Besi

Canlı ağırlık

Cidago yüksekliği

Göğüs çevresi

\section{The Structure of Beef Production and Determination of Some Body Measurements in Fattened Cattle in Bolu Province}

\begin{abstract}
In this study, it was aimed to determine the structural status of the fattening activity and some body measurements of cattle in cattle fattening farms in Bolu province. The material of the research consisted of 339 head cattle of all breed, age and both sexes that fattening in 9 fattening farms. In addition to collection information about fattening activity in farms, withers height and chest circumference were measured on cattle. Farms were grouped as 1-50 heads, $51+$ heads and above based on the number of animals. General averages for the number of animals in the groups were 19.0 heads, 75 heads and 37.7 heads. In the study, beginning of fattening and ending fattening ages were $9.7 \pm 2.23$ years and $25.6 \pm 3.57$ years, respectively. The average fattening period was determined as $15.9 \pm$ 5.21 months. The average live weights of 9-12 months age for Black and White crossbreds, Brown Swiss crossbreds, Simmental crossbred and domestic breeds were estimated as $233.9 \pm 15.25 \mathrm{~kg}, 252.7 \pm 24.33$ $\mathrm{kg}, 236.1 \pm 22.05 \mathrm{~kg}, 127.3 \pm 19.69 \mathrm{~kg}$, respectively. The average live weights for 18-22 months age for the same breeds, was estimated as $432.3 \pm 42.31 \mathrm{~kg}, 420.5 \pm 22.19 \mathrm{~kg}, 440.4 \pm 37.10 \mathrm{~kg}, 212.5 \pm 20.31 \mathrm{~kg}$, respectively.
\end{abstract}

\section{Research Article}

$\begin{array}{ll}\text { Article History } \\ \text { Received } & : 08.06 .2020 \\ \text { Accepted } & : 10.09 .2020\end{array}$

Keywords

Cattle

Fattening

Live weight

Withers height

Chest circumference

\begin{tabular}{ll}
\hline Atıf İçin: & Şahï O 2021. Bolu ilinde Sığır Besiciliği ve Besiye Alınan Sığırlarda Bazı Vücut Ölçülerinin Belirlenmesi. \\
& KSÜ Tarım ve Doğa Derg 24 (3): 663-670. https://doi.org/10.18016/ksutarimdoga.vi.749055 \\
To Cite: & Şahin O 2021. The Structure of Beef Production and Determination of Some Body Measurements in Fattened \\
& Cattle in Bolu Province. KSU J. Agric Nat 24 (3): 663-670. https://doi.org/10.18016/ksutarimdoga.vi.749055 \\
\hline
\end{tabular}

GİRIŞ

Dünya'da hayvansal protein üretiminin ürünlere göre dağılımı açısından süt ve etin payları sırasıyla \%47 ve \%27'dir. Bu ürünleri sırasıyla, su ürünleri ve yumurta 
izlemektedir. Dünya'da ve Türkiye'de kişi başına günlük ortalama hayvansal protein üretimi ise sirasiyla; 32.1 gr ve 36,3 gr'dır. (Anonim, 2013a).

Türkiye'de hayvansal protein üretimi içerisinde sütün ve etin payları sırasıyla; \%51 ve \%37'dir. Bu ürünleri sirasiyla yumurta (\%7) ve su ürünleri (\%5) izlemektedir. Türkiye'de kişi başına düşen yıllık kırmızı et (sığır, manda, koyun, keçi), tavuk eti, yumurta ve balık eti tüketimi sırasıyla; $16.3 \mathrm{~kg}, 18.8$ kg ve 6.1 kg'dır (Anonim, 2013b).

Toplam süt üretiminin yaklaşık \%90.8’i ve kırmızı et üretiminin \%89.5’ sığırlardan elde edilmektedir (Anonim, 2019). Bu değerler, hayvansal üretim politikalarında sığır yetiştiriciliğinin ağırlıkta olduğunu ortaya koymaktadır.

Gerek süt ve gerekse et üretimi açısından sığırın önemli bir kaynak durumunda olması, Türkiye'de hayvan başına verimin yükseltilmesine yönelik çalışmaların sığır popülasyonu üzerinde yoğunlaşmasına neden olmuştur.

Türkiye'de yetiştirilmekte olan sığır, koyun, keçi sayıları 2013 yılından sonra artış göstermiştir. Bu çerçevede sığır sayısı 2013-2019 yılları arasında 3.3 milyon baş artarak yaklaşık 17.7 milyon baş'a ulaşmıştır (Anonim, 2019a).

Türkiye'deki toplam sı̆̆ır, koyun, keçi ve manda sayıları sırasıyla; 17.688.139 baş, 37.276.050 baş, 11.205.429 baş ve 184.192 baş'tır. Bolu ilinde ise sığır, koyun, keçi ve manda varlığı sırasıyla; 135.300 baş, 102.150 baş, 28.431 baş ve 1.694 baş'tır. Bolu ilinin sahip olduğu sığır, koyun, keçi ve manda varlığının Türkiye'deki toplam hayvan varlığ payları sırasiyla; \%0.76, \%0.91, \%0.25 ve \%0.92 olarak hesaplanmıştır. Sığır varlığı içerisinde kültür ırklarının payı ise Türkiye ve Bolu ili için sırasıyla; $\% 83.30$ ve \%60.54'dür. Kültür ırkı sığır varlığını, kültür ırkı melezleri (Türkiye ve Bolu ili için sırasıyla; $\% 12.80$ ve \%33.20) ve yerli irklar (Türkiye ve Bolu ili için surasıyla; \%3.80 ve \%6.26) takip etmektedir. Toplam çiğ süt üretimi Türkiye ve Bolu ili için yine sirasiyla; 22.960.379 ton ve 1.706.216 ton'dur (Anonim 2019a, Anonim 2019b).

Çalışma alanı olarak seçilen Bolu ili topraklarının kapladığı alan $8.323 \mathrm{~km}^{2}$ olup, Türkiye yüzölçümünün \%1.06'sını teşkil etmektedir. Bolu ilinin \%56'sını dağlar ve \%8'ini ise ovalar oluşturmaktadır. Merkez ilçe haricinde 8 İlçesi, 4 beldesi ve 511 köyü vardır. Bolu ili, Türkiye'nin Batı Karadeniz Bölgesinde, $30^{\circ} 32^{\prime}$ ve $32^{\circ} 36^{\prime}$ doğu boylamları, $40^{\circ} 06^{\prime}$ ve $41^{\circ} 01^{\prime}$ kuzey enlemleri arasında yer almaktadır. Bolu ilinin batısında; Sakarya ve Düzce, güneybatısında; Bilecik ve Eskişehir, güneyinde; Ankara, doğusunda; Çankırı ve Karabük, kuzeyinde; Zonguldak illeri vardır. Genel olarak Bolu ili, Batı Karadeniz ve Karadeniz iklim tiplerine sahiptir. Bunun yanında güneybatı bölümlerinde Marmara ve İç Anadolu iklim tipleri de görülmektedir. Son 52 yıllık verilere göre ortalama günlük güneşlenme süresi 5 saat 49 dakika, yıllık yağı sayısı ise 137 gündür (Anonim 2019c).

Hayvansal üretimin arttırılmasına yönelik uygulanan ulusal ve bölgesel politikaların başarısı, hayvansal üretimin sosyal, ekonomik, kültürel ve teknik yönleriyle incelenmesi ve envanterin sağlıkl bir şekilde ortaya konulmasını amaçlayan araştırmalar ile mümkündür. Bu çalışmada da, Bolu ilinde sığır besiciliği konusunda faaliyet gösteren özel işletmelerin incelenmesi suretiyle, il'de siğır besisi konusunda mevcut durumun tespit edilmesi ve besiye alman sığırlarda bazı vücut özelliklerinin (cidago yüksekliği, göğüs çevresi, canlı ağırlık) belirlenmesi amaçlanmıştır.

\section{MATERYAL ve METOD}

Materyal

Araştırmanın materyalini, Bolu ilinde 2 ilçeye bağlı 4 köyde faaliyet gösteren 9 adet sığır besi işletmesi ve bu işletmelerde besiye alınmış olan çeşitli genotip, yaş ve cinsiyetteki toplam 329 baş besi sığırı oluşturmuştur.

\section{Metot}

Belirlenen işletmelerde öncelikli olarak, besi faaliyetine yönelik bilgilerin toplanması maksadıyla işletme sahipleri ile yüz yüze anket ve görüşme yöntemi kullanılmıştır (Boyar ve Yumak 1999). Çalışma kapsamında besinin farklı dönemlerinde olan işletmelerde besi periyodunun başında ve besi periyodunun sonunda hayvanlara yedirilen kaba ve yoğun yem miktarları ile ilgili bilgiler de toplanmıştır. Ayrıca işletmelerde besiye alınan 339 baş sığırın yaş ve cinsiyeti tespit edilerek, hayvanların vücut ölçüleri (cidago yüksekliği, göğüs çevresi ve canlı ağırlık) belirlenmiştir. Kültür ırkı ve melezlerinin canlı ağırlıklarının tahmin edilmesinde doğrudan ölçme şeridi üzerindeki kilogram değer esas alın mıştır. Yerli ırklarda ise canlı ağırlık tahmininde ölçme şeridinde santimetre ölçüsü esas alınarak daha önce yerli ırklar üzerinde yapılan bir çalışma sonucunda elde edilen regresyon eşitliği kullanılmıştır (Thieme 1983).

$\left(C A=22.91-0.964 * G C+0.0151 *(G C)^{2}\right)$

Bu eşitlikte; CA: Canlı Ă̆grlık, GÇ: Okunan göğüs çevresi ölçüs̆ü (cm)

Sığır besi işletmeleri, besideki hayvan sayısına göre, 150 baş ve 51 baş ve üzeri sığır kapasitesi olmak üzere iki işletme büyüklük grubuna ayrılmıştır (Kıral 1993, Uzal ve Uğurlu 2006).

\section{Örnekleme Yöntemi:}

Araştırma başlangıcında, işletme ve hayvan varlığına ilişkin sağlıklı ve güncel veri olmaması nedeniyle hızlı kırsal değerlendirme yöntemi kullanılmıştır. Hızlı 
Kırsal Değerlendirme (HKD); informal tarım sörveyi, hızlı keşif, informal metot, keşif sörveyi, bilgi değerlendirmesi, hızlı değerlendirme programı, katılımcı kırsal değerlendirme gibi birçok şekilde adlandırılmıştır (Beebe 1995). Yöntem çerçevesinde, Tarım ve Orman İl Müdürlüğü yetkilileriyle görüşülerek sığır besiciliğinin yoğun yapıldığı Bolu Merkez ve Gerede ilçeleri belirlenmiştir. Merkez ve Gerede Tarım ve Orman ilçe Müdürlükleri yetkilileri ile yapılan görüşmeler neticesinde ise yalnızca sığır besiciliği konusunda faaliyet gösteren 9 adet özel besi işletmesi tespit edilmiştir.

\section{İstatistik Analizler}

İstatistiki analizler, besi işletmelerinin faaliyetlerinin değerlendirilmesi ile ırk ve cinsiyet grupları itibariyle tanımlayıcı istatistiklerin belirlenmesinden oluşmuştur. Verilerin hazırlanmasında Excel paket programı kullanılmış olup, Minitab (Anonim 1997) programı yardımıyla anket sonuçlarına ait frekansların yanı sıra besideki sığırların ırk ve cinsiyet grupları itibariyle cidago yüksekliği, göğüs çevresi ve canlı ağırlığa ait tanımlayıcı istatistikler (ortalama, standart hata, minimum ve maksimum) hesaplanmıştır.

\section{BULGULAR ve TARTIŞMA}

İşletme büyüklük grupları itibariyle, işletmelerin 6'sı 1-50 baş sığıra sahip işletmelerden, 3'ü ise 51 ve daha fazla sayıda sığıra işletmeleri oluşmuştur. Bu araştırmada elde edilen değer, Akman ve Yener (1989), Türkiye'de besi işletmesi varlığ 1 ve kapasiteleri konusunda yapmış oldukları araştırmada, 100 baş'ın altında sığıra sahip işletmeler için buldukları değerden (\%96) düşük, Kıral (1993) tarafından Ankara ilinde besi işletmeleri üzerinde yürüttüğü çalışmada 150 baş kapasite için bildirmiş olduğu değerden yüksek ve 51-100 baş sığır kapasitesi için bildirdiği değerden düşük bulunmuştur. Uzal ve Uğurlu (2006), Konya ilindeki besi işletmelerinin yapısal analizi konusunda yaptıkları çalışmada, kapalı ve bağlı sisteme sahip 150 baş işletme büyüklük grubu için bildirmiş oldukları değer, bu araştırmada elde edilen değerden düşük bulunmasına karşılık 51 baş ve üzeri sığır kapasitesi için bildirdikleri değer, bu araştırmada tespit edilen değere yaklaşık bulunmuştur.

Bu çalışmada besiye alınmış olan sığırların ırk ve sığır tipi itibariyle dağılımları Çizelge 1'de verilmiştir.

Çizelge 1. Besideki sı̆̆ırların ırk ve sığır tipi itibariyle dağılımları

Table 1. Distribution of cattle in fattening by breeds

\begin{tabular}{|c|c|c|c|}
\hline Irk / Tip Grub & & $\begin{array}{c}\text { Siğır Sayısı (baş) } \\
\text { (Cattle Number (head)) }\end{array}$ & $\begin{array}{l}\text { Oran (\%) } \\
\text { (Rate (\%)) }\end{array}$ \\
\hline \multirow{4}{*}{$\begin{array}{l}\text { Yerli Irklar } \\
\text { (Native } \\
\text { Breeds) } \\
(\% 36.6)\end{array}$} & Yerli Kara (Native Black Cattle) & 49 & 14.4 \\
\hline & Doğu Anadolu Kırmızısı (East Anatolian Red) & 43 & 12.7 \\
\hline & Yerli Güney Sarısı (Native Southern Yellow Cattle) & 26 & 7.7 \\
\hline & Boz Step (Turkish Grey Steppe) & 6 & 1.8 \\
\hline \multirow{8}{*}{$\begin{array}{l}\text { Kültür ve } \\
\text { Kültür } \\
\text { Melezleri } \\
\text { (Culture } \\
\text { Breeds and } \\
\text { Culture } \\
\text { Crossbreeds) } \\
(\% 63.4)\end{array}$} & Siyah Alaca (Black and White) & 9 & 2.6 \\
\hline & Siyah Alaca melezleri (Black and White Crossbreed) & 40 & 11.8 \\
\hline & Esmer (Brown $S_{w i s S}$ ) & 6 & 1.8 \\
\hline & Esmer melezleri (Brown Swiss Crossbreeds) & 81 & 23.9 \\
\hline & Simental (Simmental) & 40 & 11.8 \\
\hline & Simental Melezi (Simmental Crossbreeds) & 35 & 10.3 \\
\hline & Jersey Melezi (Jersey Crossbreeds) & 4 & 1.2 \\
\hline & Alt Toplam (Total) & 339 & 100.0 \\
\hline \multirow{4}{*}{$\begin{array}{l}\text { Siğır Tipi } \\
\text { (Cattle } \\
\text { Type) }\end{array}$} & Tosun (Steer) & 238 & 70.0 \\
\hline & Kısır İnek (Infertile Cow) & 68 & 20,0 \\
\hline & Düve (Heifer) & 33 & 10.0 \\
\hline & Alt Toplam (Total) & 339 & 100.0 \\
\hline
\end{tabular}

Bu çalışmada, besiye alınmış olan sığırların \%63.4'ünü kültür ırkı ve melezleri ve \%36.6'sını lokal veya yerli irklar oluşturmuştur. Irklar itibariyle besideki sığırlar içerisinde ilk sırayı Esmer melezleri (\%23.9) almıştır. $\mathrm{Bu}$ ırkı sırasıyla; Yerli Kara ırkı (\%14.4), Doğu Anadolu Kırmızısı ırkı (\%12.7), Siyah Alaca melezleri (\%11.8), Simental (\%11.8) ve Simental melezleri (\%10.3) izlemiştir.

İşletmelerde besiye alınmış olan sığırlar tosun, kısır inek ve düvelerden oluşmaktadır. Tosun, kısır inek ve düvelerine oranları ise sirasiyla; $\% 70, \% 20$ ve $\% 10$ olarak hesaplanmıştır.

Ağır ve Akbay'ın (2017), çalışmalarında besideki sığırlardan inek için (\%18.0), düve için (\%8.26) ve tosun için (\%29.47) bildirişleri bu araştırmada elde edilen değerlerden düşük bulunmuştur.

$\mathrm{Bu}$ araştırmada, besi işletmelerinde besiye alınan ortalama sığır sayıları 1-50 baş, $51+$ baş ve işletmelerin geneli için sırasıyla; 19.0 baş, 75 baş ve 37.7 baş olarak tespit edilmiştir. 
İşletmeler geneli için tespit edilen ortalama sığır sayısı (37.7 baş), Uzal ve Uğurlu (2006) tarafından Konya ilinde yapılan sı̆̆ır besiciliği için bildirilen değerden (70 baş) düşük, Aydın ve Sakarya (2012) tarafından Kars ve Erzurum illerinde yürütülen çalışmada besideki ortalama hayvan sayısı için bildirdikleri değerden (31.8 baş) yüksek bulunmuştur.

Çalışmaya konu olan besi işletmelerinde uygulanan besi süresine ilişkin bilgiler Çizelge 2'de verilmiştir.

Çalışmada ele alınan işletmelerin geneli için besi süresinin 10 ay ila 24 ay arasında değiştiği tespit edilmiş olup, ortalama besi süresi ise 15.9 ay olarak belirlenmiştir (Çizelge 2).

Çelik ve Sarı̈zkan'ın (2017), Kırşehir ili Merkez ilçesinde sığır besiciliği için bildirdikleri besi süresi (241.1 gün) ve Gezginç ve Günlü (2020) tarafından yürütülen çalışma için bildirilen 303.16 günlük süre ile Budağ ve Keçeci (2013) tarafindan Van ilinde yürütülen çalışmada işletmelerin $\% 76$ 'sı için bildirilen 120 günlük besi süresi, bu araştırmada işletmeler geneli için elde edilen ortalama besi süresinden $(15,9$ ay) düşük bulunmuştur.

Çalışmada ele alınan işletmelerde besi başı ve besi sonunda hayvanlara yedirilen kaba ve yoğun yem miktarları Çizelge 3'de verilmiştir.

Çizelge 2. Besi süresi ile ilgili bilgiler

Table 2. Information on the fattening period

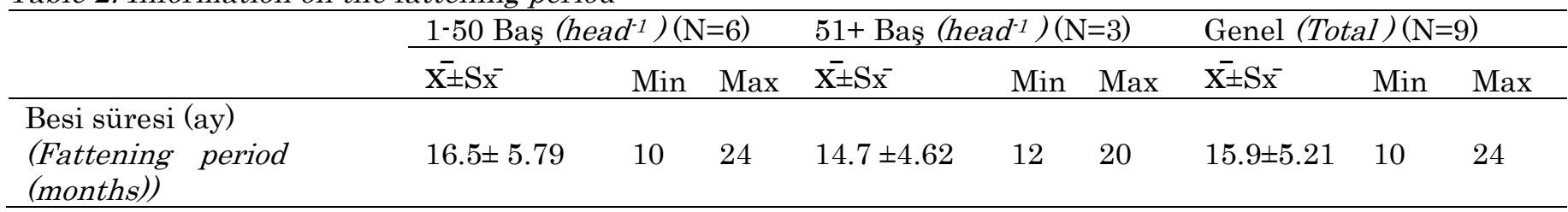

Çizelge 3. Besi periyodunda hayvanlara verilen kaba veya yoğun yem miktarları ( $\left.\mathrm{kg} \mathrm{baş}^{-1}\right)$

Table 3. The amount of roughage or mixed feeds given to animals during the fattening period $\left(\mathrm{kg}\right.$ head $\left.{ }^{-1}\right)$

\begin{tabular}{|c|c|c|c|c|c|}
\hline & \multicolumn{2}{|c|}{$\begin{array}{l}\text { Günlük Kaba Yem Miktarı } \\
\text { (Amount of roughage per animal per day) }\end{array}$} & \multicolumn{2}{|c|}{$\begin{array}{l}\text { Günlük Yoğun Yem Miktarı } \\
\text { (Amount of mixed feed per animal per day) }\end{array}$} \\
\hline & & $\begin{array}{l}\text { Besi Başlangic1 } \\
\text { (At the beginning } \\
\text { of the fattening period) }\end{array}$ & $\begin{array}{l}\text { Besi Sonu } \\
\text { (At end of the } \\
\text { fattening period) }\end{array}$ & $\begin{array}{l}\text { Besi Başlangicl } \\
\text { (At the beginning } \\
\text { of the fattening period) }\end{array}$ & $\begin{array}{l}\text { Besi Sonu } \\
\text { (At end of the } \\
\text { fattening period) }\end{array}$ \\
\hline \multirow{3}{*}{$\begin{array}{l}1-50 \text { Baş } \\
(\mathrm{N}=6)\end{array}$} & $\overline{\mathrm{X} \pm \mathrm{Sx}}$ & $10.0 \pm 0.00$ & $10.0 \pm 0.00$ & $3.7 \pm 1.33$ & $4.7 \pm 1.89$ \\
\hline & Min & 10 & 10 & 2.5 & 2.5 \\
\hline & Max & 10 & 10 & 6 & 7.5 \\
\hline \multirow{3}{*}{$\begin{array}{l}51+\text { Baş } \\
(\mathrm{N}=3)\end{array}$} & $\overline{\mathrm{X} \pm \mathrm{Sx}}$ & $9.0 \pm 5.29$ & $8.0 \pm 3.61$ & $3.3 \pm 1.54$ & $4.8 \pm 2.57$ \\
\hline & Min & 5 & 5 & 2 & 2 \\
\hline & Max & 15 & 12 & 5 & 7 \\
\hline \multirow{3}{*}{$\begin{array}{l}\text { Genel } \\
(\mathrm{N}=9)\end{array}$} & $\overline{\mathrm{X} \pm \mathrm{Sx}}-$ & $9.3 \pm 4.35$ & $8.5 \pm 3.11$ & $3.5 \pm 1.31$ & $4.7 \pm 1.97$ \\
\hline & Min & 5 & 5 & 2 & 2 \\
\hline & Max & 15 & 12 & 6 & 7.5 \\
\hline
\end{tabular}

(kg baş-1 ): Hayvan başına yedirilen günlük kaba veya yoğun yem miktarı

$\left(\mathrm{kg} \mathrm{head}^{-1}\right)$ : The amount of raughage or mixed feeds per animal per day

Besi başı ve besi sonunda sığırlara yedirilen kaba yem miktarı 1-50 baş işletme grubunda aynı miktarda (10.0 $\mathrm{kg}$ ) kalırken, 51 ve daha fazla sayıda sığıra sahip işletme grubunda besi başlangıcında yedirilen kaba yem miktarının $(9.0 \mathrm{~kg})$ besi sonu dönemde bir miktar azaltıldığ $(8.0 \mathrm{~kg})$ tespit edilmiştir. Diğer taraftan besi başlangıç dönemi ve besinin son döneminde yedirilen yoğun miktarları, 1-50 baş kapasiteli işletme grubunda sirasiyla; $3.7 \mathrm{~kg}$ ve $4.7 \mathrm{~kg}$, 51 ve daha fazla sayıda sığır besleyen işletme grubunda ise yine sırasıyla; $3.3 \mathrm{~kg}$ ve $4.8 \mathrm{~kg}$ olarak hesaplanmıştır (Çizelge 3).

Çizelge 3'de verilen değerlerden hareketle, işletmeler geneli için besinin başlangıç döneminde, yem rasyonundaki kaba yem ve yoğun yem oranları sirasıyla; \%72.7 ve \%27.3, besinin son döneminde ise, yem rasyonundaki kaba yem ve yoğun yem oranları sırasıyla; \%64.4 ve \%35.6 olarak hesaplanmıştır.

Budağ ve Keçeci (2013) tarafindan Van ilinde yürütülen çalışmada, işletme grupları itibariyle besi başlangıç dönemindeki kaba yem oranı \%30 ila \%50, yoğun yem oranı ise \%50 ila \%70 arasında değiştiği bildirilmiştir. Aynı araştırmada besi sonu dönemde ise kaba yem oranı \% 20 ila \%40, yoğun yem oranı ise $\% 60$ ila \%80 arasında değişmiştir. Ele alınan işletme grupları itibariyle besi başlangıç ve besinin son dönemlerinde yem rasyonundaki kaba yem oranları, bu çalışmada elde edilen değerden düşük bulunurken, her iki dönemde de yem rasyonundaki yoğun yem oranı için elde edilen değerler bu çalışmada elde edilen 
değerden yüksek bulunmuştur.

Irk ve yaş grupları itibariyle erkek sığırlara ait vücut ölçüleri ve tahmini canlı ağırlık sonuçları Çizelge 4'de verilmiştir.

Besideki 9-12 aylık yaştaki Siyah Alaca ırkı, Siyah Alaca ırkı melezleri, Esmer ırkı melezleri, Simental ırkı melezleri ve yerli ırklar için ortalama canlı ağırlıklar sırasıyla; $257.5 \mathrm{~kg}, 233.9 \mathrm{~kg}, 252.7 \mathrm{~kg}, 236.1$ $\mathrm{kg}$ ve $127.3 \mathrm{~kg}$ olarak tahmin edilmiştir (Çizelge 4).

Basspinar (1991) tarafindan Siyah Alaca ırkı x Yerli Kara ırkı melezleri üzerinde yürüttüğü araştırmada, besi başlangıç dönemi canlı ağırlığı için elde ettiği değer $(260.6 \mathrm{~kg})$, bu araştırmada Siyah Alaca melezleri için elde edilen değerden yüksek bulunmuştur.

Nazlıgül (1995) tarafından Esmer ırkı x Doğu Anadolu Kırmızısı ırkı melezleri üzerinde yürüttüğü araştırmada, besi başlangiç dönemi canlığı ağırlığı için elde ettiği değer $(186.4 \mathrm{~kg})$, bu araştırmada Esmer ırkı melezleri için elde edilen değerden düşük bulunmuştur.

Koç ve Akman (2003) tarafından ithal edilen Siyah Alaca ırkı tosunlarda yürütülen besi denemesinde, besi başlangıç canlı ağırlığı bakımından hafif ve ağır gruplar için elde ettikleri değerler $(246.4 \mathrm{~kg}$ ve 387.4 $\mathrm{kg}$ ), bu araştırmada Siyah Alaca için elde edilen değerden yüksek bulunmuştur.

Özdoğan (2007) tarafından Aydın ilinde yürütülen çalışmada, besi başlangıç döneminde ortalama canlı ağırlıklar bakımından Siyah Alaca ırkı için $(258.0 \mathrm{~kg})$ elde ettiği değer, bu araştırmada elde edilen değere yaklaşık bulunmuştur.

Gözener ve Sayılı'nın (2014) Tokat ili Turhal ilçesinde yürüttükleri çalışmada, besi başlangıç ağırlığı açısından melez ırklar için (94.4 kg) ve yerli ırklar için $(94.4 \mathrm{~kg})$ elde ettikleri değerler, bu araştırmada tespit edilen değerlerden düşük bulunmuştur.

Bu çalışmada, 9-12 aylık yaş aralığındaki Siyah Alaca melezleri için tespit edilen değerin $(233.9 \mathrm{~kg})$, Başpınar'ın (1991) bildirdiği değerden (260.6 kg) yüksek olması, ilgili araştırmadaki sığırların daha erken yaşta (7-8 ay) besiye alınmış olmalarından, yine bu çalışmada, Siyah Alaca ırkı için tespit edilen değerinin (257.5 kg), Koç ve Akman'ın (2003) aynı ırka mensup ağır ve hafif gruplar için ölçtükleri değerlerden (246.4 kg ve $387.4 \mathrm{~kg})$ düşük bulunması, söz konusu araştırmadaki sığırların daha geç yaşta (12-18 ay) besiye alınmalarından, diğer taraftan Özdoğan'ın (2007) Siyah Alaca ırkı için bildirdiği değerin $(258.0 \mathrm{~kg})$ bu çalışmadaki değere yakın olması ise benzer yaş aralığında (8-10 ay) besiye alınmış olmasından kaynaklandığı düşünülmektedir.

Besideki 18-22 aylık yaştaki sığırlarda Siyah Alaca ırkı, Siyah Alaca ırkı melezleri, Esmer ırkı melezleri, Simental ırkı melezleri ve yerli ırklar için ortalama canlı ağırlıklar sırasıyla; $460.3 \mathrm{~kg}, 432.3 \mathrm{~kg}, 420.5 \mathrm{~kg}$,
$440.4 \mathrm{~kg}$ ve $212.5 \mathrm{~kg}$ olarak tahmin edilmiştir (Çizelge 4).

Başpınar (1991) tarafından Siyah Alaca ırkı x Yerli Kara ırkı melezleri üzerinde yürüttüğü araştırmada, besinin son dönem canlı ağırlığı için elde ettiği değer $(506.4 \mathrm{~kg})$, bu araştırmada Siyah Alaca ırkı melezleri için elde edilen değerden $(432.3 \mathrm{~kg})$ yüksek bulunmuştur.

Nazlıgül (1995) tarafından Esmer ırkı x Doğu Anadolu Kırmızısı melezleri üzerinde yürüttüğü araştırmada, besinin son döneminde ölçülen ortalama canlığ̣ ağırlığı $(366.4 \mathrm{~kg})$, bu araştırmada Esmer ırkı melezleri için elde edilen değerden $(420.5 \mathrm{~kg})$ düşük bulunmuştur.

Koç ve Akman (2003) tarafından ithal edilen Siyah Alaca ırkı tosunlarda yürütülen besi denemesinde besi sonu canlı ağırlığı bakımından hafif grup için elde ettiği değer $(399.6 \mathrm{~kg})$, bu araştırmada Siyah Alaca ırkı için elde edilen değerden $(460.3 \mathrm{~kg})$ düşük, ağır grup için elde ettikleri değer $(507.3 \mathrm{~kg})$ ise yüksek bulunmuştur.

Özdoğan (2007) tarafından Aydın ilinde yürütülen çalışmada, besinin son dönemi olan 6. ayında ortalama canlı ağırlıklar bakımından Siyah Alaca ırkı için $(502.36 \mathrm{~kg})$ ve Esmer $1 r k ı$ için $(518.48 \mathrm{~kg})$ elde ettiği değerler, bu araştırmada aynı ırklar için elde edilen değerlerden yüksek bulunmuştur.

Gözener ve Sayılı'nın (2014) Tokat ili Turhal ilçesinde yürüttükleri çalışmada, ortalama besi sonu canlı ağırlığı açısından melez irklar (267.3 kg) ve yerli ırklar $(216.2 \mathrm{~kg})$ için elde ettikleri değerler ile ortalama besi süresi açısından melez ırklar (165.0 gün) ve yerli ırklar (139.4 gün) için tespit edilen değerler, bu araştırmada tespit edilen değerlerden (15.9 ay) düşük bulunmuştur.

Besideki 24 aylık yaştan büyük erkek sığırlarda ortalama cidago yüksekliği, gögüs çevresi ve tahmini canlı ağırlık sırasıyla, $133.9 \mathrm{~cm}, 189.7 \mathrm{~cm}$ ve $558.5 \mathrm{~kg}$ olarak hesaplanmıştır (Çizelge 4).

Besideki kısır ineklere ait vücut ölçüm ve tahmini canlı ağırlık sonuçları Çizelge 5'de verilmiştir. Besideki kısır ineklerde ortalama cidago yüksekliği, göğüs çevresi ve tahmini canlı ağırlık sırasıyla, 128.1 $\mathrm{cm}, 179.4 \mathrm{~cm}$ ve $467.8 \mathrm{~kg}$ olarak hesaplanmıştır.

Kısır inekler ve 24 aylık yaştan büyük erkek sığırlarda ortalama canlı ağırlıklar sırasıyla; $467.8 \mathrm{~kg}$ ve 558.5 kg olarak tahmin edilmiştir (Çizelge 5).

\section{SONUÇ ve ÖNERİLER}

Bolu ilinde sığır besiciliği yapan özel işletmelerde yürütülen bu çalışmanın neticesinde; besi için ırk tercihi bakımından, besi performansının iyi olması nedeniyle kültür ırkı ve kültür ırkı melezlerinin (\%63.4), cinsiyet bakımından besi performansı ve canlı ağırlık kilogram satış fiyatının yüksek olması nedeni 
Cizelge 4. Irk ve yaş grupları itibariyle erkek sığırların vücut ölçüleri ve canlı ağırlıklarına ait bilgiler

Table 4. Information on body measurements and live weights of male cattle by breed and age groups

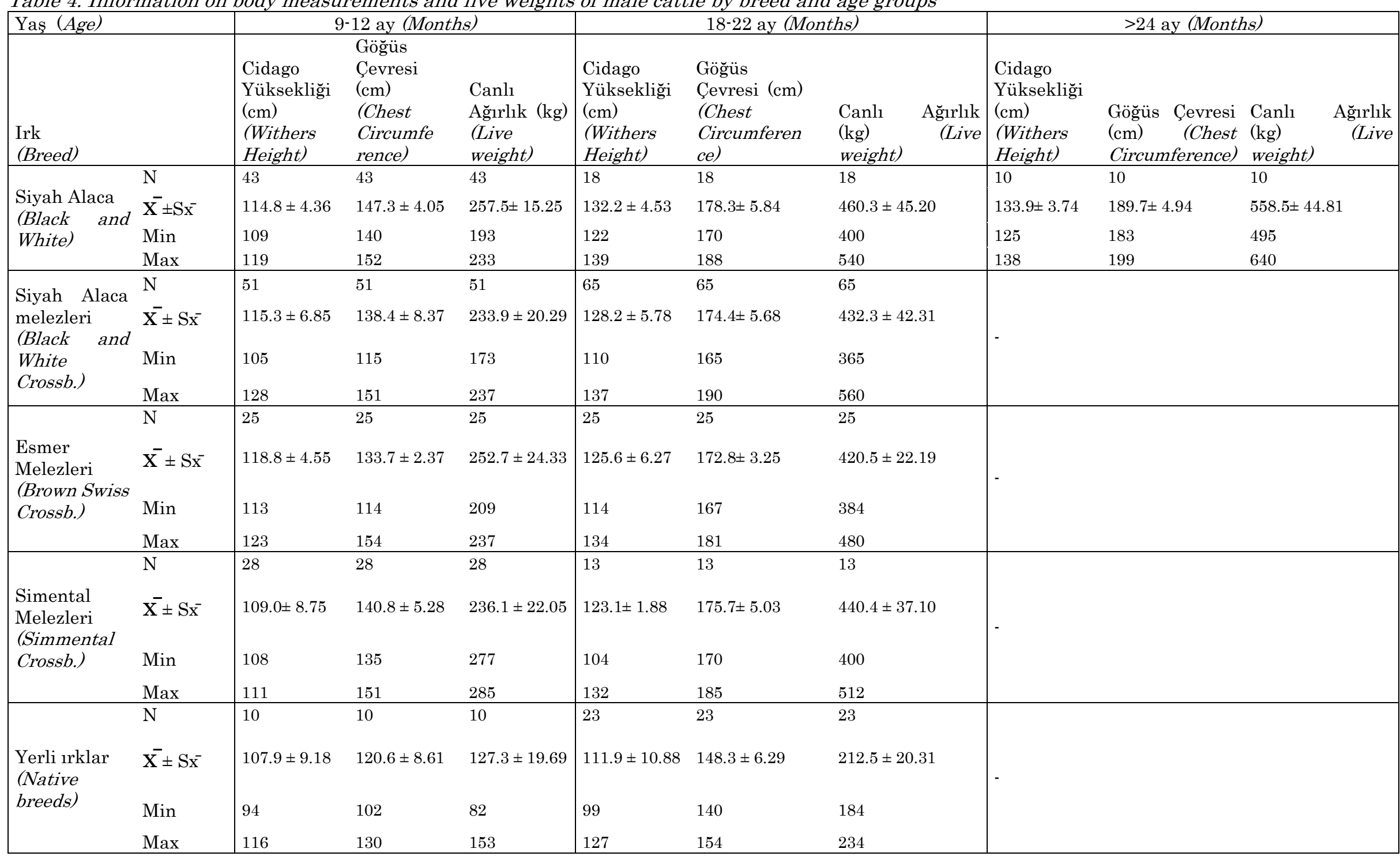


Çizelge 5. Besideki kısır ineklere ait vücut ölçüleri ve canlı ağırlık ile ilgili bilgiler

Table 5. Information on body size and body live weight of infertile cows.

Cidago Yüksekliği $(\mathrm{cm}) \quad$ Göğüs Çevresi $(\mathrm{cm})$

(Withers Height)

(Chest Circumference)

Canlı Ağırlık (kg)

(Live weight)

\begin{tabular}{|c|c|c|c|c|c|c|c|c|c|c|}
\hline Irk & & $\overline{\mathrm{X}^{ \pm}}$ & & & $\overline{\mathrm{X} \pm}$ & & & $\overline{\mathrm{X}_{ \pm}}$ & & \\
\hline (Breeds) & $\mathrm{N}$ & $\mathrm{Sx}^{-}$ & Min & Max & $S x^{-}$ & Min & Max & $\mathrm{Sx}^{-}$ & Min & Max \\
\hline $\begin{array}{l}\text { Siyah Alaca } \\
\text { (Black and } \\
\text { White) }\end{array}$ & 18 & $\begin{array}{c}128.1 \pm \\
4.53\end{array}$ & 120 & 136 & $\begin{array}{c}179.4 \pm \\
4.39\end{array}$ & 171 & 184 & $\begin{array}{c}467.8 \pm \\
31.08\end{array}$ & 408 & 503 \\
\hline
\end{tabular}

ile erkek sığırların (\%70) daha fazla tercih edilmektedir. İ'de yaygın olarak yetiştirilmekte olan Esmer irkı ve melezleri (\%25.7), Simental ve melezleri (\%22.1) ve Siyah Alaca ve melezlerinin (\%14.4) beside daha çok tercih edildiği belirlenmiştir. Ayrıca sığırların besiye başlama yaşlarının benzer çalışmaların çoğunluğunda 7-10 ay arasında değiştiği dikkate alındığında, bu çalışmada sığırların besiye başlama yaşlarının (9-12 ay) nispeten biraz yüksek olduğu anlaşılmaktadır. Buna ek olarak işletmelerde uygulanan besi süresinin nispeten benzer çalışmalara göre daha uzun (15.9 ay) olması ve yedirilen kaba yem oranının besi dönemi boyunca (besi başlangicı ve besi sonunda sirasiyla, \%72.7 ve \%64.4 ) yüksek, yoğun yeme oranının (besi başlangıcı ve besi sonunda sırasiyla, \%27.3 ve \%35.6) düşük tutulduğu görülmüştür. Benzer araştırmalarda besi döneminde yedirilen yem rasyonundaki kaba yem oranının \%2050 ve yoğun yem oranının \%50-80 arasında değiştiği düşünüldüğünde, bu çalışmada irklar itibariyle elde edilen besi sonu canlı ağırlıkların diğer çalışmalara nispetle düşük olması, besi dönemi boyunca yedirilen yem rasyonundaki kaba yem/yoğun yem oranından kaynaklandığ̣ düşünülmektedir. Besi süresinin çok uzun tutulması da yapılan besicilik faaliyetini ekonomik olmaktan çıkarmaktadır.

$\mathrm{Bu}$ çalışmada elde edilen bulguların ışığında, besi için canlı hayvan materyali seçimi, uygun barınak koşullarının sağlanması, besi süresi boyunca besleme tekniği ve ekonomik besiciliğin yanı sıra besi sığırlarında koruyucu hekimlik konularında besicilerin mesleki bilgi ve becerilerinin arttırılmasına yönelik kursların düzenlenmesi ve yayım çalışmalarının yapılmasının faydalı olacağı düşünülmektedir.

Ankara ve İstanbul gibi büyükşehirlere coğrafik konumu itibariyle yakın olan Bolu ili, pazar imkânları açısından önemli bir avantaja sahip durumdadır. İ'de sığgr besiciliğinin gelişmesi, kasaplık canlı hayvan ve karkas et arzının artmasına ve Il'in ekonomisine katkı sağlaması beklenmektedir.

\section{TEŞEKKÜR}

Saha çalışmalarına vermiş oldukları desteklerden dolayı Tarım ve Orman Bakanlığı ve Bolu İl Tarım ve Orman Müdürlüğüne teşekkür ederim. Bu çalışmanın kaynağı, 095668 tez numarası ile YÖK Tez Merkezine kayıtlı "Bolu ilinde sığır yetiştiriciliğinin yapısı" başlıklı doktora tez çalışmasıdır.

\section{Araştırmacıların Katkı Oranı Beyan Özeti}

Araştırmanın tasarlanması, veri toplama, kaynak araştırması ve makalenin yazımı makale yazarı tarafından yapılmıştır.

\section{Çıkar Çatışması Beyanı}

Makale yazarı, herhangi bir çıkar çatışması olmadığını beyan eder.

\section{KAYNAKLAR}

Ağır HB, Akbay C 2017. Adana İlinde Sözleşmeli ve Sözleşmesiz Besi Sığırcılığ İşletmelerinin Ekonomik Analizi. Journal of Agricultural Faculty of Gaziosmanpasa University, 34 (3):139-147.

Akman N, Yener SM 1989. Crossbreeding for Beef Production in Turkey. Tarım Alanında Türk ve Alman Üniversiteleri İşbirliğinin Bilimsel Sonuçları. 26-30 September 1989 İzmir.

Anonim 2013a. Dünya'da Hayvansal Protein Üretiminin Hayvansal Ürünlere Göre Dağılımı. http://www.fao.org/faostat/en/\#compare \& http://www.fao.org/countryprofiles/index/en/?iso3= TUR (Erişim tarihi: 21.03.2020).

Anonim 2013b. Türkiye'de Kişi Başına Hayvansal Ürünler Tüketimi. http://www.fao.org/country profiles/index/en/?iso3=TUR （Erişim tarihi: 21.03.2020).

Anonim 2019a. Hayvansal Üretim İstatistikleri, Türkiye istatistik Kurumu. (Erişim tarihi: 30.06.2020).

Anonim 2019b. Hayvansal üretim istatistikleri, Türkiye İstatistik Kurumu, Kocaeli Bölge Müdürlüğü.

Anonim 2019c. Bolu Illi Hakkında Genel Bilgiler, Bolu Belediyesi resmi web sitesi. https://www.bolu.bel.tr/bolu/ (Erişim tarihi: 27.06.2020).

Aydın E Sakarya E 2012. Kars ve Erzurum İlleri Entansif Sığır Besi Işletmelerinin Ekonomik Analizi. Kafkas üniversitesi Veteriner Fakültesi Dergisi 18 (6): 997-1005.

Başpinar H 1991. Holştayn x Yerli Kara F1 Melezi Erkek Danaların Yarı Acık Ahır Koşullarında Besi 
Performansı ve Karkas Özellikleri. Lalahan Hay. Araşt. Enst. Derg. 31 (3-4): 1-8.

Beebe J 1995. Basic Concepts and Techniques of Rapid Appraisal. Human organization, 54 (1): 42-51.

Boyar S, Yumak H 1999. Isparta ve Burdur İlleri Süt Sı ̆̆ırcılığ İşletmelerinde Kaba ve Karma Yem Mekanizasyon Düzeyi, Karşılaşılan Sorunlar ve Çözüm Önerileri. Yüzüncü Yıl Üniversitesi, Ziraat Fakültesi, Tarım Bilimleri Dergisi 10(1): 11-18.

Budağ C, Keçeci Ş 2013. Van'da Büyükbaş Hayvan Besilerinde Kullanılan Yemler ve Besi Şekillerine İlişkin Bir Anket Çalışması. Van Yüzüncü yıl Üniversitesi Fen Bilimleri Dergisi 18(1-2): 48-61.

Çelik Ç, Sarıözkan S, 2017. Kırşehir İli Merkez İlçesinde Sığır Besi Yapan İşletmelerin Ekonomik Analizi, Harran Üniv Vet Fak Derg 6 (1): 38-45.

Gezginç Ö, Günlü A 2020. Konya İli Kadınhanı ve Sarayönü İlçelerinde İthal ve Yurt İçinden Temin Edilen Hayvanlarla Sığır Besi Yapan İşletmelerin Ekonomik Analizi. Erciyes Üniversitesi Veteriner Fakültesi Dergisi 17(1): 1-9.

Gözener B, Sayılı M 2014. Tokat İli Turhal İlçesinde Sı̆̆ır Besinde Üretim Maliyeti ve Canlı Ağırlık Artışına Etki Eden Faktörler. Ankara Üniversitesi, Tarım Bilimleri Dergisi 21: 288-289.
Kıral T 1993. Ankara ilinde T. Şeker Fabrikaları A.Ş. Besi Bölge Şefliği Tarafından Desteklenen Sığır Besi Işletmelerinin Ekonomik Analizi. Ankara Üniversitesi Yayınları: 1289.

Koç A, Akman N 2003. Farklı Ağırlıkta Besiye Alınan İthal Edilmiş Siyah-Alaca Tosunların Besi Gücü ve Karkas Özellikleri. Hayvansal Üretim 44(1): 26-36.

Microsoft Soft., 1997. Microsoft Office 97Microsoft Corporation, USA.

Nazlıgül A 1995. Esmer X Doğu Anadolu Kırmızısı Melezi (F1) Tosunların Yarı Açık Ahır Şartlarında Besi Performansları. Lalahan Hay. Araşt. Enst. Derg. 35 (3-3): 16-25.

Özdoğan M 2007. Aydın İli Yaz Mevsimi Koşullarında Esmer ve Siyah Alaca Siğırların Bazı Besi Performansı Özellikleri Üzerine Bir Araştırma. Aydın Adnan Menderes Üniversitesi, Hayvansal Üretim 48(2): 1-6.

Thieme, O 1983. Aus dem Institut für Tierzucht und Haustiergenetic_der Georg-August-Universitat Göttingen.

Uzal S, Uğurlu N 2006. Konya İli Besi Sığırı İşletmelerinin Yapısal Analizi. Selçuk Üniversitesi Ziraat Fakültesi Dergisi 20 (40): 131-139. 